\title{
ANALISIS PERANAN PALANG MERAH INDONESIA (PMI) KOTA MADIUN DALAM MENGIMPLEMENTASIKAN NILAI-NILAI PANCASILA SILA KEDUA
}

\author{
Alfiantika Febrian Ashari*
}

\begin{abstract}
Abstrak
$\mathrm{P}$ enelitian ini bertujuan untuk mengetahui Peranan Palang Merah Indonesia (PMI) Kota Madiun Dalam Mengimplementasikan Nilai-nilai Pancasila Sila Kedua serta manfaat yang dapat diperoleh masyarakat kota Madiun dengan adanya bantuan-bantuan dari PMI.

Jenis penelitian yang digunakan adalah penelitian kualitatif deskriptif. Penentuan sampel dalam penelitian ini dengan proporsional dimana yang menjadi informan yaitu staf PMI dan masyarakat kota Madiun yang jumlahnya 10 informan. Teknik pengumpulan data menggunakan teknik wawancara, observasi dilengkapi dokumentasi. Data hasil penelitian dianalisis melalui reduksi data, penyajian data, dan penarikan simpulan atau verifikasi.

Hasil penelitian menunjukkan bahwa Palang Merah Indonesia (PMI) kota Madiun berperan dalam mengimplementasikan nilai-nilai Pancasila sila kedua. Berdasarkan dengan temuan data, hal ini dapat dilihat dari berbagai kegiatan kemanusiaan yang telah dilakukan oleh PMI sebagai wujud dalam mengembangkan sikap saling mencintai sesama manusia, mengakuinya dan memperlakukan sesuai dengan harkat dan martabatnya sebagai makhluk Tuhan Yang Maha Esa, guna untuk menjunjung tinggi nilai-nilai kemanusiaan. Dari berbagai kegiatan kemanusiaan yang telah dilakukan oleh PMI tersebut tentunya sangatlah bermanfaat untuk masyarakat yang terkena dampak bencana yang memerlukan bantuan secara adil dan sukarela. Serta dapat memberikan pertolongan bagi para pasien atau penderita sakit yang sangat membutuhkan darah melalui kegiatan donor darah yang diadakan PMI.
\end{abstract}

\section{Kata Kunci: Palang Merah Indonesia (PMI), Nilai-nilai Pancasila Sila Kedua.}

\footnotetext{
* Mahasiswa Prodi PPKn IKIP PGRI Madiun
} 


\section{PENDAHULUAN}

Manusia sejak dilahirkan adalah sebagai makhluk sosial di tengah keluarganya. Manusia tidak dapat berdiri sendiri tanpa bantuan orang lain. Manusia memerlukan mitra untuk mengembangkan kehidupan yang layak bagi kemanusiaan. Sebagai individu, manusia dituntut untuk dapat mengenal serta memahami tanggung jawabnya bagi diri sendiri dan masyarakat. Kecenderungan manusia untuk hidup berkelompok bukanlah sekedar naluri atau keperluan yang diwariskan secara biologis semata, melainkan dalam kenyataannya manusia berkumpul sampai batas-batas tertentu juga menunjukkan adanya ikatan sosial. Mereka berkumpul dan saling berinteraksi satu sama lain. Interaksi antar manusia merupakan suatu kebutuhan dalam rangka memenuhi kebutuhan hidup.

Dan didalam kehidupan manusia, tentu tidaklah lepas dari suatu problematika atau permasalahan yang dialaminya. Contohnya masalah yang menimpa manusia seperti bencana alam, tentulah manusia memerlukan bantuan orang lain untuk meringankan penderitaannya. Seperti kita ketahui bersama saat ini bangsa Indonesia banyak dilanda bencana alam baik itu banjir, tanah longsor, aktivitas gunung api dan lain-lain. Dengan kondisi yang terjadi diatas tersebut semua elemen-elemen yang terkait yang berperan dalam upaya pencegahan dan penanggulangan bencana alam saling bekerja sama untuk menangani hal tersebut. Tidak luput juga peran Palang Merah Indonesia (PMI) sebagai salah satu organisasi kemanusiaan.

Palang Merah Indonesia (PMI) adalah sebuah organisasi perhimpunan nasional di Indonesia yang bergerak dalam bidang sosial kemanusiaan. PMI selalu berpegang teguh pada tujuh prinsip dasar Gerakan Internasional Palang Merah dan Bulan Sabit Merah yaitu Kemanusiaan, Kesamaan, Kesukarelaan, Kemandirian, Kesatuan, Kenetralan, dan Kesemestaan. Palang Merah Indonesia tidak berpihak pada golongan politik, ras, suku ataupun agama tertentu. Palang Merah Indonesia dalam pelaksanaannya juga tidak melakukan pembedaan tetapi mengutamakan objek korban yang paling membutuhkan pertolongan 
segera untuk keselamatan jiwanya. ( Skagata, 2013: 1).

Berbicara organisasi kemanusiaan, pasti tidak akan pernah lepas dari nilai-nilai Pancasila. Kedua unsur tersebut saling terikat dan berhubungan. Dikata demikian, karena dalam pelaksanaan organisasi kemanusiaan tetap berpegang pada Pancasila sebagai indikator dan tolak ukur.

Karena nilai-nilai Pancasila itu bagi bangsa Indonesia menjadi landasan dasar serta motivasi atas segala perbuatan baik dalam kehidupan sehari-hari maupun dalam kehidupan kenegaraan. Dengan kata lain, nilai-nilai Pancasila merupakan cita-cita tentang kebaikan yang harus diwujudkan menjadi suatu kenyataan (TIM Dosen PKn IKIP PGRI Madiun. $2008: 50$ ).

Dalam kaitannya dengan Palang Merah Indonesia, terkandung nilainilai kemanusiaan didalamnya. Nilai kemanusiaan yang adil dan beradap secara sistematis didasari dan dijiwai oleh sila Ketuhanan Yang Maha Esa, serta mendasari dan menjiwai ketiga sila berikutnya. Sila kemanusiaan sebagai dasar fundamental dalam kehidupan kenegaraan, kebangsaan, dan kemasyarakatan. Nilai kemanusiaan ini bersumber pada dasar filosofis antropologis bahwa hakikat manusia adalah susuan kodrat rokhani (jiwa) dan raga, sifat kodrat individu dan makhluk sosial, kedudukan kodrat makhluk pribadi berdiri sendiri dan sebagai makhluk Tuhan Yang Maha Esa (Kaelan. 2001: 186).

Dengan didasarkan atas keimanan dan ketaqwaan terhadap Tuhan Yang Maha Esa, menjadi kewajiban bagi seluruh umat manusia untuk saling menolong dalam penderitaan tanpa membedakan agama, bangsa, suku bangsa, golongan, warna kulit, jenis kelamin, bahasa, dan pandangan politik. Dengan dilandasi rasa kemanusiaan yang adil dan beradap dan dengan didorong semangat Gerakan Internasional Palang Merah dan Bulan Sabit untuk meringankan penderitaan sesama manusia dibentuklah Palang Merah Indonesia (PMI) sebagai suatu organisasi kemasyarakatan yang bergerak di bidang sosial kemanusiaan dan turut memelihara budi pekerti luhur menuju kearah terwujudnya masyarakat yang berkeadilan sosial. 
Berdasarkan hal tersebut, peneliti ingin meneliti lebih jauh tentang penelitian dengan judul: "Analisis Peranan Palang Merah Indonesia (PMI) Kota Madiun dalam Mengimplementasikan Nilai-nilai Pancasila Sila Kedua”.

\section{METODE PENELITIAN}

Penelitian ini dilaksanakan di markas PMI kota Madiun jalan Parikesit no. 08 kota Madiun. Waktu yang diperlukan dalam penelitian ini yaitu selama 6 bulan dari bulan Februari 2015 sampai dengan bulan Juli 2015. Penelitian yang digunakan peneliti dalam penelitiannya menggunakan pendekatan deskriptifkualitatif. Menurut Nana Syaodih Sukmadinata (2007:60), menjelaskan bahwa penelitian kualitatif adalah suatu penelitian yang ditujukan untuk mendiskripsikan dan menganalisis fenomena, peristiwa, aktivitas sosial, sikap, kepercayaan, persepsi, pemikiran orang, secara individual maupun kelompok. Sedangkan jenis penelitian ini adalah adalah deskriptif. Penelitian deskriptif memusatkan perhatian pada masalah aktual sebagaimana adanya pada saat penelitian berlangsung. Melalui penelitian deskriptif, peneliti berusaha mendeskripsikan peristiwa dan kejadian yang menjadi pusat perhatian tanpa memberikan perlakuan khusus terhadap peristiwa tersebut. Variabel yang diteliti bisa tunggal bisa juga lebih dari satu variabel. (Juliansyah Noor, 2011 : 34$35)$.

Jenis data merupakan data yang didapat dari informan. Jenis data ada 2 jenis yaitu:

\section{Data Primer}

Menurut Joko Subagyo (2004: 87), data primer adalah data yang diperoleh secara langsung melalui observasi dan wawancara. Data primer diperoleh secara mentahmentah dari masyarakat dan masih memerlukan analisa lebih lanjut.

\section{Data Sekunder}

Data sekunder adalah data yang tidak langsung memberikan data kepada pengumpul data misalnya lewat orang lain atau dokumen (Sugiyono, 2013: 308).

Adapun teknik pengumpulan data yang dipergunakan penulis dalam penelitian ini adalah sebagai berikut:

\section{Teknik Observasi}

Menurut Syaodih N (dalam Djam'an Satori dan Aan Komariah , 2012: 105) mengatakan bahwa 
"observasi atau pengamatan merupakan suatu teknik atau cara mengumpulkan data dengan jalan mengadakan pengamatan terhadap kegiatan yang sedang berlangsung".

\section{Wawancara}

Menurut Sudjana (dalam Djam'an Satori dan Aan Komariah, 2012: 130) wawancara adalah proses pengumpulan data atau informasi melalui tatap muka antara pihak penanya (interviewer) dengan dengan pihak yang ditanya atau penjawab (interviewee).

\section{Dokumentasi}

Satori dan Komariah (2012:147) menyatakan dokumen merupakan rekaman kejadian masa lalu yang ditulis atau dicetak, dapat berupa catatan anekdotal, surat, buku harian dan dokumen-dokumen. Untuk mendapatkan data yang valid dan kredibel dalam penelitian diperlukan teknik keabsahan data.

Dalam penelitian ini peneliti menggunakan teknik trianggulasi. Menurut Sugiyono, (2013: 241) "dalam teknik pengumpulan data, triangulasi diartikan sebagai teknik pengumpulan data yang bersifat menggabungkan dari berbagai teknik pengumpulan data dan sumber data yang telah ada".

Adapun analisis data selama dilapangan menurut model Milles dan Huberman (Satori dan Komariah, 2012: 218-220) ada 3 yaitu sebagai berikut:

\section{Reduksi Data (Reduction)}

Ketika peneliti mulai melakukan penelitian tentu saja akan mendapatkan data yang banyak dan relative beragam dan bahkan sangat rumit. Itu sebabnya, perlu dilakukan analisis data melalui reduksi data. Data yang diperoleh ditulis dalam bentuk laporan atau data yang terperinci. Laporan yang disusun berdasarkan data yang diperoleh direduksi, dirangkum, dipilih hal-hal yang pokok, difokuskan pada hal-hal yang penting.

\section{Penyajian Data (data display)}

Selanjutnya sesudah mereduksi data adalah menyajikan data (data display). Teknik penyajian data dalam penelitian kualitatif dapat dilakukan dalam berbagai bentuk seperti tabel, grafik dan sejenisnya. Lebih dari itu, penyajian data bisa dilakukan dalam bentuk uraian singkat, bagan, hubungan antar kategori, flowchart dan sejenisnya. Adapun fungsi 
display data disamping untuk memudahkan dan memahami apa yang terjadi, juga untuk merencanakan kerja selanjutnya berdasarkan apa yang telah dipahami tersebut.

\section{Conclusion}

\section{Drawing/Verification}

Langkah ketiga dalam analisis data kualitatif menurut Milles and Huberman adalah penarikan kesimpulan dan verifikasi. Kesimpulan awal yang dikemukakan masih bersifat sementara, dan akan berubah bila tidak ditemukan buktibukti yang kuat yang mendukung pada tahap pengumpulan data berikutnya.

Kesimpulan dalam penelitian kualitatif adalah merupakan temuan baru yang sebelumya belum pernah ada. Temuan dapat berupa deskripsi atau gambaran suatu obyek yang sebelumnya masih belum jelas atau gelap sehingga setelah diteliti menjadi jelas, dapat berupa hubungan kausal atau interaktif, hipotesis atau teori.

\section{PEMBAHASAN}

\section{A. Peranan Palang Merah Indonesia (PMI) kota Madiun.}

Dari hasil wawancara dengan staf PMI mengatakan bahwa pada dasarnya peranan Palang Merah

Indonesia adalah membantu masyarakat dibidang sosial kemanusiaan. Seperti membantu masyarakat yang terkena dampak bencana, baik bencana alam maupun bencana akibat ulah manusia dan bertujuan untuk membantu mengurangi penderitaan manusia. Sifatnya netral, sukarela dan adil sehingga dalam hal memberikan pertolongan PMI tidak membedabedakan suku, keturunan, agama, kepercayaan, jenis kelamin, kedudukan sosial, warna kulit, dan sebagainya serta tidak meminta imbalan apapun.

PMI selalu siap siaga untuk membantu masyarakat yang membutuhkan pertolongan dengan kesiapsiagaan bantuan dan penanggulangan bencana dari PMI yang dibantu oleh relawan yang telah mendapatkan pelatihan pertolongan pertama. PMI juga berperan dalam memberikan pelayanan kesehatan kepada masyarakat, seperti kegiatan donor darah baik itu donor darah keliling maupun donor darah yang dilakukan di 
unit donor darah dan juga

pembinaan donator darah, pemeriksaan golongan darah, bakti sosial, pelayanan kendaraan atau ambulan gawat darurat, pelayanan pos pertolongan pertama misalkan pada saat hari raya dan di keramaian.

Selain itu PMI juga berperan dalam pembinaan Palang Merah Remaja (PMR) disekolah-sekolah terutama sekolah ditingkat sekolah atas. PMI memberikan penyuluhan tentang tugas PMR dan kegiatan ini sangat penting untuk memberikan pemahaman kepada anggota PMR, sebab mereka merupakan ujung tombak PMI dalam memberikan penyuluhan kepada masyarakat. Selain berperan membina PMR, PMI juga berperan memberikan pembinaan anak sekolah melalui pendidikan atau program Pendidikan Remaja Sebaya (PRS), Unit Kesehatan Sekolah (UKS), Jumpa Bakti Gembira (Jumbara).

B. Manfaat yang diperoleh masyarakat kota Madiun dengan adanya bantuan dari PMI. a. Penderitaan masyarakat yang terkena dampak bencana bisa berkurang.

Dari hasil wawancara dengan masyarakat kota Madiun mengatakan bahwa PMI telah berperan cukup besar dalam membantu masyarakat, misalnya saat terjadi berbagai bencana alam yang melanda di berbagai wilayah kota Madiun seperti bencana banjir di wilayah kecamatan Mangunharjo dan disekitar kelurahan Kelun kecamatan Kartoharjo, serta bencana angin puting beliung PMI turut membantu memberikan kebutuhan pokok kepada korban yang membutuhkan seperti misalkan makanan atau minuman dan pakaian layak pakai, pelayanan kesehatan, serta dapur umum dan tidak hanya itu PMI juga sangat terbuka dengan korban bencana, mendengarkan keluh kesah dan memberikan motivasi kepada korban supaya dapat berlapang dada dalam menghadapi cobaan 
yang sedang melanda dan

pendampingan langkah

selanjutnya dengan suasana

hangat dalam berkomunikasi.

PMI juga turut membantu memadamkan api sewaktu terjadi kebakaran yang terjadi di PLN kota Madiun. Dengan bantuan-bantuan dari PMI tersebut dapat meringankan penderitaan masyarakat yang terkena dampak bencana, baik penderitaan fisik maupun psikis.

b. Berperan

dalam meningkatkan

kesejahteraan

dan

\section{kesehatan masyarakat}

Sangat berguna untuk masyarakat seperti transfusi darah atau kegiatan donor darah yang dapat memberikan manfaat dan pertolongan bagi para pasien atau penderita sakit yang sangat membutuhkan darah. Kegiatan donor darah tidak hanya bermanfaat bagi para pasien atau penderita sakit yang membutuhkan darah saja, tetapi juga sangat bermanfaat bagi pendonor darah itu sendiri. Karena dengan donor darah akan membuat pendonor lebih sehat dan dapat mengurangi resiko terkena penyakit. Selain itu pendonor juga mendapat pelayanan gratis dari PMI misalkan dapat mengetahu kondisi kesehatan dan melakukan konseling kesehatan secara gratis tanpa harus mengeluarkan biaya yang besar.

\section{c. Pelayanan sosial}

PMI juga sigap dalam mengantisipasi hal-hal yang tidak diinginkan dipusat keramaian, misalkan pada saat acara konser musik, malam pergantian tahun baru, dan lain sebagainya, dengan mendirikan layanan posko PMI yang berguna untuk memberikan pertolongan pertama, layanan kesehatan, dan evakuasi jika terdapat korban pingsan dikarenakan kelelahan diantara desakandesakan penonton lain ditengah keramaian ataupun bahkan akibat tawuran yang mengakibatkan korban terluka dan cedera. Untuk itu posko 
pelayanan PMI sangat penting adanya dipusat keramaian untuk mengantisipasi agar tidak ada korban jiwa. Semua bisa teratasi dengan cepat dan tepat melalui layanan posko PMI ditengah keramaian.

\section{PENUTUP}

\section{Simpulan}

1. PMI kota Madiun berperan dalam mengimplementasikan nilai Pancasila Sila Kedua hal ini terbukti PMI telah melakukan kegiatan kemanusiaan, misalnya kegiatan pelayanan transfusi darah untuk pertolongan bagi para pasien atau penderita sakit yang sangat membutuhkan darah. Dan pada saat suatu daerah terkena musibah atau bencana, baik bencana alam ataupun bencana akibat ulah manusia, PMI membantu secara sukarela, netral, dan adil tanpa membedabedakan suku, agama, kepercayaan, jenis kelamin, kedudukan sosial, warna kulit, dan sebagainya serta selalu mendahulukan korban yang paling parah, yang bertujuan untuk meringankan penderitaan sesama manusia yang disebabkan oleh bencana alam atau akibat ulah manusia. Hal yang dilakukan PMI tersebut adalah sebagai wujud dalam mengembangkan sikap saling mencintai sesama manusia, serta mengakui dan memperlakukan manusia sesuai dengan harkat dan martabatnya sebagai makhluk Tuhan Yang Maha Esa, guna untuk menjunjung tinggi nilai-nilai kemanusiaan.

2. Bantuan-bantuan dari PMI benarbenar bermanfaat bagi masyarakat kota Madiun, yaitu diantaranya :

a. Penderitaan masyarakat yang terkena dampak bencana bisa berkurang. Dengan kesiapsiagaan bantuan dan penanggulangan bencana, PMI telah berperan cukup besar dalam membantu masyarakat dengan membantu memberikan bantuan kepada korban bencana seperti kebutuhan pokok, obat-obatan, dapur umum, pelayanan kesehatan serta memotivasi korban dengan suasana hangat dalam berkomunikasi.

b. Dengan adanya kegiatan transfusi darah atau donor 
darah, dapat memberikan manfaat dan pertolongan bagi para pasien atau penderita sakit yang sangat membutuhkan darah. Dan juga bermanfaat bagi pendonor darah itu sendiri karena dengan donor darah akan membuat pendonor lebih sehat, mengurangi resiko terkena penyakit dan mendapat pelayanan kesehatan gratis dari PMI.

c. Dengan adanya layanan posko PMI dipusat keramaian dapat mengantisipasi agar tidak ada korban jiwa dengan memberikan pertolongan pertama, layanan kesehatan, dan evakuasi jika terdapat korban pingsan, bahkan terluka maupun cedera.

\section{Saran}

\section{Untuk Pemerintah}

Untuk mewujudkan suatu kesejahteraan sosial masyarakat dengan dilandasi rasa kemanusiaan yang adil dan beradab diharapkan pemerintah mampu menjalin kerjasama yang baik dengan PMI. Mendukung tugas-tugas pokok PMI yang membantu pemerintah dibidang sosial kemanusiaan seperti memberikan bantuan sarana dan prasarana yang dibutuhkan PMI agar kegiatan PMI dalam membantu masyarakat yang terkena bencana dapat berjalan dengan baik dan lancar.

\section{Untuk Staf PMI Kota Madiun}

Diharapkan PMI kota Madiun tidak lengah dalam menghadapi berbagai situasi bencana di masyarakat karena masyarakat senantiasa membutuhkan pertolongan cepat dan tepat. Dan PMI perlu meningkatkan pembinaan terhadap generasi muda dalam penanggulangan bencana, kepedulian sosial, dan aksi amal melalui pendidikan atau program Pendidikan Remaja Sebaya (PRS), Palang Merah Remaja (PMR), Unit Kesehatan Sekolah (UKS), Jumpa Bakti Gembira (Jumbara). Sebab mereka merupakan ujung tombak PMI dalam memberikan penyuluhan kepada masyarakat. Dengan demikian kader PMI ditengah masyarakat akan terus bertambah.

\section{Untuk Masyarakat}

Perlu adanya perhatian dan kerjasama dari masyarakat untuk turut serta membantu PMI kota Madiun dalam menolong masyarakatmasyarakat yang sedang 
membutuhkan pertolongan. Misalnya dengan menjadi sukarelawan PMI bagi yang mampu, menyumbang dana sosial untuk korban bencana dengan seikhlasnya, dan ikut serta menjadi pendonor darah secara rutin agar dapat disumbangkan ke orang-orang yang sangat memerlukan. Dengan adanya kerjasama dari masyarakat tersebut akan tercipta suatu masyarakat yang berperikemanusiaan yang adil dan beradab.

\section{DAFTAR PUSTAKA}

Kaelan. 2001. Pendidikan Pancasila. Yogyakarta: Paradigma.

Noor, Juliansyah. 2011. Metodologi Penelitian. Jakarta: Kencana.

Satori, Djam'an. 2012. Metodelogi Penelitian Kualitatif. Bandung: Alfabeta.

Skagata. 2013. Pengertian dan Sejarah Palang Merah Indonesia, (online). http://wkb57.blogspot.com/20 13/05/pengertian-sejarahpalang-merah.html, diunduh pada 19 Maret 2015.

Subagyo, Joko. 2004. Metode Penelitian Dalam Teori dan Praktek. Jakarta: Rineka Cipta.

Sugiyono. 2013. Cara Mudah Menyusun: Skripsi, Tesis, dan Disertasi. Bandung: Alfabeta.
(2013). Metode Penelitian Kombinasi (Mixed Methods). Bandung: Alfabeta.

Sukmadinata, Nana Syaodih. 2007. Metode Penelitian Pendidikan. Bandung: Remaja Rosdakarya.

TIM Dosen Pendidikan Pancasila. 2008. Pendidikan Pancasila. Madiun: IKIP PGRI MADIUN. 